\title{
Kan gode bygg bidra til psykiatrisk behandling?
}

\author{
Ved Knut Bergsland
}

\section{Gode fysiske omgivelser kan bidra til gode behandlingsmiljøer. I artikkelen drøftes fysiske aspekter som må vektlegges for å oppnå gode omgivelser, og det legges stor vekt på at man må unngå preg av akuttsykehus i psykiatriske institusjoner. Sikkerhetsaspekter og suicidforebyggende fysiske forhold vurderes. Arkitektenes bidrag blir trolig best når de trekkes inn fra starten av planleggingen.}

\section{Kan utforming påvirke \\ behandlingsresultatet?}

Innen somatikken finnes det voksende evidens for at el ementer i fysisk utforming påvirker behandlingsresultatet (U Irich et al., 2006). Dette gjelder også i noen grad innen psykisk helsevern, selv om det finnes langt færre undersøkelser som dokumenterer effekter av gode omgivelser på dette området. En engelsk studie (Phiri \& Lawson, 2003) viste imidlertid at fysisk utforming har innflytelse på hvordan pasienter og personale i en nyoppusset avdeling oppfattet behandlingen. Pasientene kom seg signifikant raskere i den nye enn i den gamle avdelingen. 0 ppholdstida ble redusert med $14 \%$, og pasientene tilbrakte kortere tid i sikkerhetsavdelinger. A ndre forhold enn gode omgivelser kan tenkes å gjøre seg gjeldende, for eksempel $\mathrm{H}$ awthorne-effekten av innflytting i nytt bygg. Lignende resultater - riktignok udokumenterte - finner vi også i N orge. A kuttpsykiatrisk seksjon ved Sykehuset Telemark så for eksempel $50 \%$ reduksjon av uro og 30-50\% mindre bruk av nevroleptika etter innflytting i nye lokaler i 2001 (Egil W al denstrøm, personlig meddelelse, 2005). Vi vet at omgivel sene bidrar til atmosfæren på en behandlingsinstitusjon og til pasienters opplevelser og sinnsstemning (Kolstad, 2007). Vakre omgivelser gir gode assosiasjoner til det som skjer i institusjonen, og påvirker pasienters opplevelse av så vel behandler som behandlingen på en positiv måte. 0 gså pårørendes holdninger endres (O 'D ea, 2005). Førsteinntrykket er særlig viktig. Det er altså grunn til å tro at en bevisst utforming av de fysiske omgivelsene kan bidra positivt til det samlede behandlingsmiljøet, men det er ikke gitt hvilke faktorer som er særlig viktige.

Både pasientene, personalet og det samlede behandlingsmiljøet påvirkes og formes av omgivelsene, trolig mer jo lenger man er der. Det er lett å bli passivisert, infantilisert - og for personalets del hjemmeblind. Den psykiatriske enheten bør derfor ha et preg som motvirker institusjonalisering, påvirker på ønsket måte og gir ønskede signaler. O m mulig bør omgivelsene motvirke psykiatriske symptomer og svare til ønsket behandlingsresultat. $H$ vis for eksempel lavt sel vbilde skal møtes med status og mestring, må kvalitet i omgivel sene (materialbruk og utforming) være en del av det fysiske svaret (Bergsland, 1991). H va kvalitetene konkret skal bestå i, må være tema for diskusjonene om utbyggingsprinsippene for den enkelte nybyggings- eller ombyggingsoppgaven. H vis utgangspunktet for behandlingen er å gjenvinne realitetssans og normalitet og forberede pasienten på ny uavhengighet må bygningene bidra, også slik at personalet bygger oppunder dette.

Hva kjennetegner gode omgivelser i behandlingsinstitusjoner?

Det finnesikke systematiserte erfaringer om karakteristika ved gode behandlingsbygg for psykiatri. Ser man internasjonale eksempler på bygg som regnes som "gode", finner man imidlertid mange av de samme elementene som i tilsvarende norske.

$N$ oen viktige plan prinsipper:

- unngå preg av akuttsykehus

- nok plass

- oversiktlige, lett fattbare anlegg, gode orienteringsmuligheter

- opplevd kontroll over omgivelsene.

Det som primært kjennetegner akuttsykehuset, er store bygg med mange etasjer, lange korridorer uten retningsendringer, flatt lys, repetisjon av dører og rom. Dårlige orienteringsmuligheter skaper unødig stress for pasienter som $\mathrm{i}$ mange tilfelle er engstelige når de kommer. For å unngå institusjonspreg bør det derfor legges opp til små døgnenheter med korridorer som oppleves korte 18-30 m med sidelys for å lette orienteringen (A lexander, 1975). Korridorene kan gjerne ha retningsendringer. Det bør være utsikt til natur. Bygningene bør så langt råd ikke ha mer enn 1-2 etasjer, døgnenheter på bakkeplan og poliklinikkvirksomhet i 2.etasje. Det er så vidt vites ikke påvist behandlingsmessige fordeler ved høyere bygg. M å man ha høyere bygg, for eksempel i bymessige strøk, er det mulig å få til utearealer oppe i etasjene ved ulike kreative løsninger.

$\mathrm{N}$ ok plass betyr at det må tas hensyn til at pasienter i psykotisk fase har et stort revir, og man bør derfor lage store fellesrom, gjerne med flere flukt- eller retrettmuligheter. Det må også bety god oversikt over fellesarealene, inkludert lange siktlinjer, men utformingen må være slik at pasientene ikke føler seg overvåket.

Korridorene kan gjerne være så brede at de kan brukestil enkle samtaler, eventuelt ha med vinduer med plass til sittegrupper, eller enkle aktiviteter. Pasientrom må være så store og utformet slik at pasienter ikke kan barrikadere seg. For å få så mange funksjonsrom som mulig på bruttoareal et, går man ofte på akkord med behovet for nok plass i fellesområdene. Korridorene bør så langt råd er, brukes som noe mer enn rene gangarealer. Dagens krav til areal effektivitet (brutto-/ nettofaktor på 1,5) gjør at dette kan være vanskelig å få til.

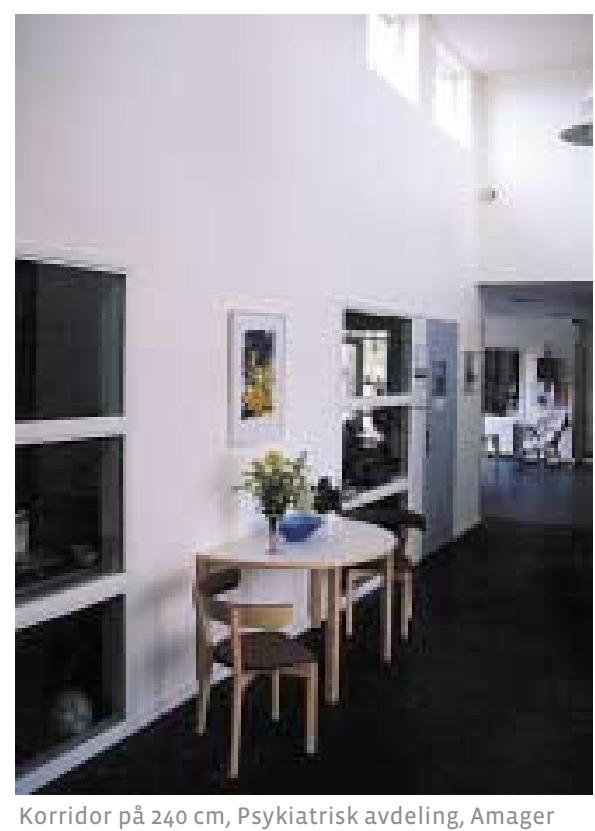
sygehus. Foto: K.Bergsland 
G ode orienteringsmuligheter krever landemerker ute og inne, tydelig hovedadkomst der pasient og pårørende kan skaffe seg overblikk og et tydelig trafikkhierarki. Få innganger, men egen akuttinngang må være hovedregelen. For at bygg skal være fattbare og oversiktlige bør de ha få innganger. Inngangspartiet bør ha en utforming som gjør det mulig å stoppe opp og skaffe seg oversikt umiddel bart innenfor hovedinngangen. Det må finnes et menneske der, som ikke bør være skjult i et glassbur. M ennesker trekkes mot lyset, og benytter helst den bredeste korridoren.

En engelsk gruppe hevder at intet psykiatribygg bør ha flere enn 75 døgn plasser i maksimalt 15-sengsenheter. Blir det flere enn dette, blir bygget lett uoversiktlig, lite fattbart og unødig institusjonspreget (C ouncil report 62, 1998). M ed differensierte enheter på 4-10 døgnplasser må man være ekstra oppmerksom på utfordringen med å sikre tilstrekkelig oversikt.

0 pplevd kontroll over egne omgivel ser gjelder primært områdene som pasientene opplever som "sine", al tså det egne rommet, omgivel sene utenfor og fellesområdene $\mathrm{i}$ enheten. Det vil blant annet si ingen kikkhull i dørene til pasientrommene. Pasientrommet må kunne møbleres på forskjellige måter. Pasienten bør kunne styre lys, temperatur mv. via enkle kontrollsystemer som ikke lar seg ødelegge.

Pasientområdene skal for øvrig gi mulighet til tilbaketrekning uten isolasjon.

Boområdene må formes og struktureres med tanke på at pasientene skal mestre omgivel sene gradvis bedre, fra det nære og private til det samfunnsmessige. Veien ut kan være et stikkord for struktureringen av den enkelte enheten. Pasientområdene må formes slik at man unngår feilsansing, og pasi entene må oppleve at de har kontroll over egne omgivelser.

Behandlingsområdene, der pasient og behandler møtes og der det foregår planlagt terapeutisk aktivitet, skal gi personalet god oversikt over pasientene, uten at de føler seg kontrollert. D et må legges opp til å hindre, avlede og skjerme uro som har oppstått. $D$ et betyr at minst ett fellesrom må være så stort - og formet slik - at flere samtaler kan føres samtidig, og gi engstelige pasienter mulighet for avstand og oversikt (Bergsland, 2000).
Lydforhold må vises særlig oppmerksomhet på grunn av tidvis høyt støynivå og mange lydfølsomme pasienter i døgnenheter. Lyddempingen i alle fellesrom bør være meget god, men det finnes eksempler på at lydisolasjonen i konsultasjonsrom har vært så god at man ikke hører alarmer som går utenfor rommet (Ö stra sjukhuset, nytt bygg, 2008). Det kan vurdereså legge inn en viss kontrollert bakgrunnsstøy for å unngå et unaturlig lavt støynivå.

\section{Sikkerhet og observasjon}

Sikkerhetsaspekter står sentralt i alle enheter for psykisk helsevern. De ulike sikringstiltakene må imidlertid veies mot pasientenes behov for å ikke føle seg kontrollert slik at det går på verdigheten løs. N oen "skjulte" fysiske tiltak blir lett oppdaget, og kan forårsake sterke pasientreaksjoner. Fengsel spregede løsninger, som metall gitter foran luftebalkonger, kan bare være nødløsninger ved dårlig utformede bygg i flere etasjer. Sannsynligvis er en planløsning som gir en uanstrengt oversikt og observasjonsmulighet over lokalene det viktigste utgangspunktet for en god sikkerhet. N ormale bygg viser tillit til pasientene. Velger man for eksempel bort musikkanlegg i fellesrom fordi de har kabler pasienter kan henge seg i, bør man kanskje heller tenke gjennom hele enhetens funksjon og ideologi på nytt.

Det er illusorisk å tro at noe sykehusbygg kan eller bør være rømningsfritt. Pasienter som vil rømme, gjør det uansett fysiske tiltak. De bør kunne få bevise for seg selv at rømning er vanskelig, men mulig. 0 mgivelsene bør kunne vise pasientene tillit og respekt, både gjennom kvalitet i møblering og utforming generelt.

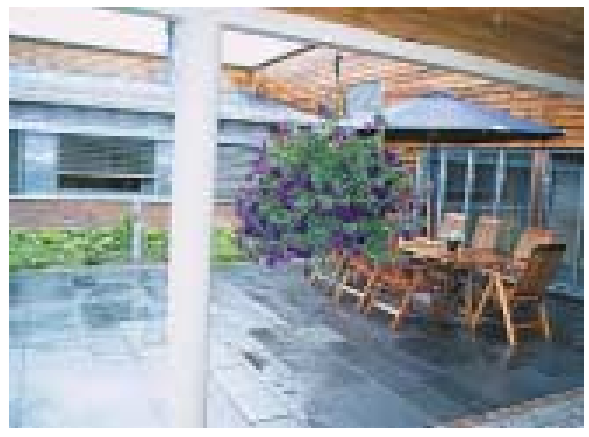

Lukket atrium, Akuttpsykiatrisk seksjon, Telemark sjukehus. Foto: K. Bergsland
Skjerming er noe man må ty til når personal et ikke har lyktes med å kjenne igjen, avlede og behandle aggressiv atferd tidlig nok. Det finnes nederlandske undersøkelser som viser at pasienters aggresjonsnivå ikke minsker signifikant etter opphold i en tradisjonell skjermingsen het (Jurgen $\mathrm{H}$ oner, personlig meddelelse, 2005). U ten å diskutere observasjonstiltak og aggresjonsnivå, kan det stilles spørsmål om det er riktig å bruke egne, atskilte lavstimulus skjermingsenheter. Som minimum bør man etter undertegnedes skjønn kunne utnytte utsikt til naturomgivel ser bevisst. Engelske undersøkelser ( $C$ urran et al. 2005) påviser en rekke svakheter ved engelske seclusion units, og anviser en rekke detaljerte forslag til forbedringer og krav. De framhever blant annet problemene med at pasienter i slike enheter deler oppholdsrom. Slike forhold er heller ikke uvanlige i N orge. D et finnes mange, utilfredsstillende løsninger i norske psykiatriske sykehusavdelinger.

\section{Kan omgivelser bidra til} å forebygge selvmord?

Suicid eller alvorlig selvskading kan skje overalt, såfremt pasienten får være alene for å utføre sitt forsett. Prinsipielt kan det derfor tenkes to ulike måter å håndtere sel vmordsforebygging på: Sørge for at pasienten aldri er alene (kontinuerlig observasjon), eller bygge inn sikkerhetstiltak som gjør selvdestruktiv atferd umulig. I praksis vil de fleste bygg utformes for en kombinasjon av observasjonsog fysiske tiltak. Tilstrekkelig personell vil alltid være den sikreste måten å forhindre selvmord på i psykiatriske enheter. D e fysiske omgivelsene kan i beste fall bidra til å lette behandlernes oversikt og sikre at pasientene føler seg trygge og opplever kontroll over omgivelsene, fra den private sfæren til uteområdene.

Et viktig spørsmål er om synlige sikkerhetstiltak bidrar til pasientenes opplevelse av trygghet, eller om pasientene føler seg overvåket og kontrollert, med mulighet for økt aggresjonsnivå. Det går hårfine grenser mellom overvåkning og oversikt, og bare i tilfeller med klare behov for kontrollert observasjon er tydelig overvåkning fornuftig. 


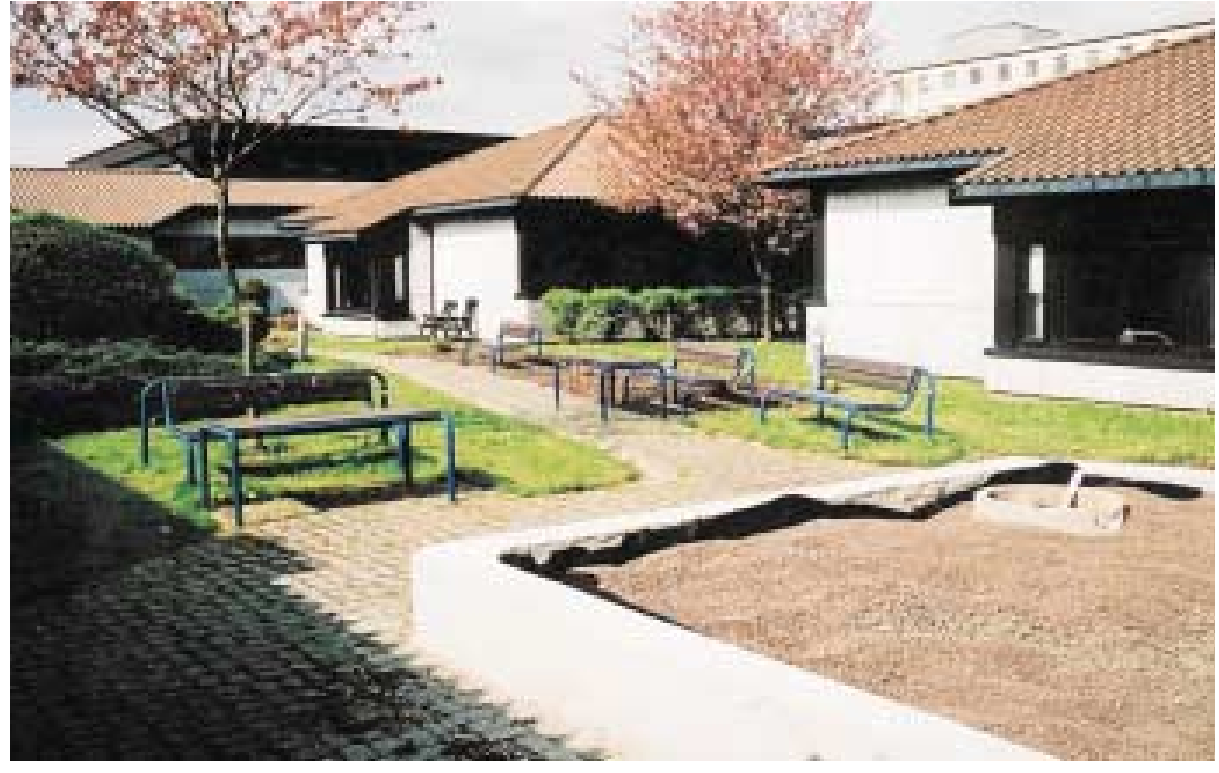

Vanndam med fisk måtte tømmes. $20 \mathrm{~cm}$ vann er dessverre nok til å gjøre suicid. Foto: K.Bergsland

I utgangspunktet bør man sørge for å kunne se de mest brukte fellesrommene uten å markere det tydelig. Dette betinger en sentralt plassert vaktenhet. Ved A kuttenheten ved Psykiatrisk avdeling i H augesund kunne personalet se det meste av fire bruksrom ved raskt å se til høyre og venstre fra den sentrale plassen utenfor vaktrommet. 0 vervåkningskameraer vil lett kunne skape aggresjon. Bruken av slike midler kan likevel skape en viss trygghet i noen situasjoner, forutsatt at bruken er diskutert og akseptert av pasientene som skal observeres.

\section{Innebygde tiltak}

Det finnes så vidt vitesikke noen samlet norsk oversikt over aktuelle forebyggende tiltak, eller noen evaluering av slike. Av tiltak som gjør det vanskelig for pasienter å finne mul igheter til selvdestruktiv atferd, kan nevnes:

- G od avstand fra gulv til himling, helst ca 3 meter.

- Sikkerhetsglass i alle vinduer

- Vinduer uten åpninger som kan brukes til å smugle ting inn og ut

- Plast - ikke glass på bilder

- Svake gardinoppheng festet med borrelås

- Brannsikkerhet - hvert rom gjøres til en branncelle

- Innebygde dusjhoder som skal ligge til grunn for utbyggingen, og hvordan arkitekten skal brukes. 0 ftest kommer arkitekten seint inn - etter at programmet er utformet. M ange mål for prosjekter lar seg ikke operasjonalisere uten god innsikt. A rkitekten bidrar trolig best når han/hun får bidra fra starten. En arkitekt uten innlevelse kan bli like farlig for psykiatriske pasienter som en psykiater uten empati.

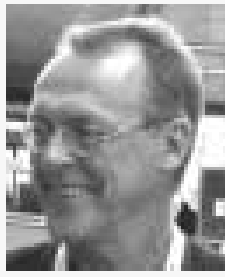

Knut H . B ergsland seniorrådgiver SIN TEF H else, sivilarkitekt N TH 1969, har arbeidet med planlegging av institusjoner i psykisk helsevern siden 1985, og vært opptatt av forholdet mellom

omgivel ser og pasientbehandling. Bergsland har forelest internasjonalt om psykiatri og fysiske omgivelser, og skrevet internasjonale artikler om samme tema. $\mathrm{H}$ an har gjort en rekke prosjekter om kapasitetsplanlegging, funksjonsvurderinger og areal bruk i psykisk helsevern for ulike HF og R H F. Bergsland er redaktør av webportalen www. sykehusplan.no, og man geårig leder av A rkitektforum for $\mathrm{H}$ elsebygg.

Dører som ikke kan barrikaderes, særlig i pasientrom

\section{- O versikt over innganger}

Det bør være enkelt å tilkalle personell - innen og mellom enheter, for eksempel ved å gjøre som ved A kuttpsykiatrisk seksjon Telemark, der man kan åpne korridordørene mellom enheter om natta ved å avmagnetisere låser, slik at personell som ikke jobber i enheten kan komme meget raskt til assistanse.

\section{Innlevelse og innsikt}

Det kreves mye omtanke og innlevelse for å omsette disse generelle spesifikasjonene til praktisk designhandling. Denne innlevelsen kommer trolig best fram når arkitekten får arbeide tett sammen med fagfolkene i planarbeidets innledende faser. I noen vellykkede prosjekter, for eksempel A kuttpsykiatrisk seksjon, Telemark sykehus, ble denne ekspertisen koplet inn fra starten. I slike tilfeller får man også sjansen til å utvikle et felles språk for planleggingsoppgaven. A Itfor ofte snakker man forbi hverandre - med de beste intensjoner. D ette gjelder både psykiatriens fagfolk, arkitekter, byggherrer og eiere. Prosjekteierne bør sette av mer tid $\mathrm{i}$ innledende faser av prosjektene til å tenke skikkelig gjennom hvilke kriterier

\section{Referanser:}

A lexander, C. et al. (1977). A pattern language: towns, buildings, construction. $\mathrm{N}$ ew York: $\mathrm{O}$ xford U niversity Press.

Bergsland, K. H. (1991). Psykiatri og fysiske omgivelser, evaluering av psykiatrisk avdeling, Fylkessjukehuset i H augesund. SIN T EF-rapport 81 A 91044

Bergsland, K. H. (2000). Psykiatri 2000, vedlegg 3. U tviklingsplan for Sør-Trøndelag psykiatriske sykehus.

Curran, C. et al (2005). Seclusion: factors to consider when designing and using a seclusion suite in a mental health hospital. $\mathrm{H}$ ospital Development. 36(1), 19-26.

Kolstad, A . (2007). H elbredende kunst - finnes det? betydningen av utsmykking og estetikk $i$ helseinstitusjoner. Tidsskrift for N orsk psykologforening, 44(8), 991-94.

Lawson, B. \& Phiri, M .(2003). T he architectural healthcare environment and its effect on patient health outcomes. Sheffield: U niversity of Sheffield.

0 'D ea, K. B. (2005). EU H PN D esign Impact Study, Final Report. EU Health Property N etwork. Royal College of Psychiatrists. (1998). N ot just bricks and mortar. Council report 62, London.

Ulrich,R.\& Zimring, C. (2004). The role of the physical environment in the hospital of the 21st century: a once in a lifetime opportunity. The Robert Wood Johnson Foundation. 